perspectives, it might seem imprudent to say that it may paradoxically be these kinds of passages where the possibility of agreement lies. I am thinking especially Wettstein's accounts of the Old Testament, and how he succeeds in seeing the existential element in those stories, which is common, if not for all, at least for many of us. (For example, I think that the story of Abraham and Isaac speaks very differently to a mother who has to send her son to war compared to a person who does not have experiences of personal loss). Here it is easy for one to find resonances with what Walters writes in his book about atheist spirituality. Yet, in the end, there can be no ultimate agreement, but hoping for understanding might not be that far-fetched, and that is something that we can experience in purely philosophical encounters between theists and atheists, where distancing oneself from the subject matter is possible. Nevertheless, there is something that haunts us, beyond the level of mere arguments. And here some atheists might agree with the note on which Wettstein ends the book: "Better to suffer in confusion about God, an appropriate state for us if not a pleasurable one, than to forgo these stories." (333)

\title{
FEDOR STANZHEVSKIY
}

Saint Petersburg State University

Vladimir K. Shokhin. Philosophy of Religion and Its Historical Forms (From Antiquity to the End of the Eighteenth Century). Moscow: Alpha-M, 2010 (В.К. Шохин, Философия религии и ее исторические бормы [античность - конеи, XVIII в.], Москва, АЛЬФА-М, 2010).

What exactly is philosophy of religion? Can we answer this question without considering the history of thought on the issue? These are some of the main questions that Vladimir Shokhin (the Chair of Philosophy of Religion at the Institute of Philosophy of the Russian Academy of Sciences and Professor of Philosophy at the Moscow State University) addresses in his book. He argues that in virtue of the self-reflective character of philosophy in general, philosophy of religion, in particular, should reflect on the history of its formation.

However, historical reflection may pursue two different tasks: the archeological reconstruction of the thought of the past and the selection of philosophically relevant aspects of historical heritage. It is the second 
task (which implies a polemical approach to the history of philosophy) that interests Shokhin as being properly philosophical.

The objective set by the Author is to reconstruct the historical development of the philosophy of religion and to offer its periodization; for that purpose he has to delimit the boundaries of the very concept of philosophy of religion. Therefore the method consists in retracing historical development through a conceptual prism. Having answered the question on what Philosophy of religion is, we can set the historical frame of its development.

The first part of the book presents different conceptions of the philosophy of religion and corresponding ways of its periodization in three philosophical realms: in the Russian, analytical and continental European contemporary thought; then the author proceeds to select those views that seem to him to be more appropriate to the range of problems that should be dealt with by philosophy of religion. After that the author suggests his own way to delimit the range of problems of the philosophy of religion and offers his periodization of its historical development based on this conception.

The first three chapters of the first part deal with the main programs of elaborating philosophy of religion and with respective methods of establishing the genesis of this discipline in Russia, in analytical philosophy and in so called continental philosophy.

The Russian philosophy of religion is still very young; as regards the delimitation of the subject-matter of the philosophy of religion, the main tendency in Russia consists in understanding the concept of philosophy of religion in two senses: taken sensu stricto it represents discourse on religion as such; while understood sensu largo it also embraces philosophical theology and religious philosophy.

The views on the genesis of philosophy of religion in analytical philosophy may be classified in three groups: 1) history of philosophy of religion is not distinct from the history of philosophy-in-religion (that is, from some philosophical aspects of religious thought). 2) The history of philosophy of religion coincides and at the same time does not coincide with philosophy-in-religion. This attitude looks for the genesis of philosophy of religion as a specialized discipline but nevertheless does not want to completely separate philosophy of religion from largely understood religious thought. 3) philosophy of religion has its own special history (for example, J. Collins derives its history from Hume, Kant and Hegel). On the whole, Anglo-American philosophy is dominated 
by a tendency to identify philosophy of religion with philosophical theology and therefore it is the 1st and 2nd options that are preferred. The very expression philosophy of religion is thus understood first of all in the sense of genetivus subiecti (as philosophy-in-religion).

As for the continental philosophy of religion, it is mostly religion in itself (and not God or Christian doctrine) that is identified as the subject matter of philosophy of religion, even though there are some attempts to combine studying religion with philosophical theology (e.g. R. Scheffler or F. von Kutschera) or with the hermeneutics of "discourse on God" (I. Dalfert).

Shokhin proceeds to elaborate a systematic conception of philosophy of religion. He does this by way of eliminating those ways of understanding it that seem to distort or excessively broaden its concept. This eliminative approach is applied to pairs of concepts forming some kind of binary tree diagram. Thus between philosophies describing religion and those tending to transform it (not unlike early Marx) we have to choose the former ones, since philosophy is called to explore reality and the opposite tendency is permeated with ideology. Philosophy of religion has its own more or less neatly delimited field of studies. The broader vision of this field embraces both philosophical theology and philosophical science of religion. This broader vision combines both discourse of religion (philosophy-inreligion) and discourse on religion (philosophy-on-religion). It is as if one tried to unite writing novels and literary critique into one and the same activity. Since such a "synthetic" program confuses two levels of language (object-language and meta-language), it has to be excluded.

This leaves us with two distinct philosophical programs: philosophical theology and philosophical study of religion. However, the subject matter of the former is not essentially distinct from traditional natural theology (which was systematized in the epoch of the second scholastics) and philosophical reconstruction of religious dogmas. Therefore it is the philosophical study of the phenomenon and language of religion, of its existential, ethical and esthetical dimensions as well as that of its metaphysical and cultural aspects that should constitute the task of the philosophy of religion. Philosophy of religion is thus "a set of rationally possible and justified applications of philosophical interest and methods to studying the multidimensional phenomenon of religion, as well as to related sciences ... and to its own discourse (due to the self-reflective character of philosophy)" (pp. 211-212). So, philosophical theology, far from being identical with philosophy of religion, is in fact one of the objects 
of study of the latter. Therefore the language of philosophy of religion is placed on the meta-level with regard to that of philosophical theology.

Thus understood, philosophy of religion is called to pursue the following tasks: the study of religiosity as such; the relation of "religion" to particular religions; definition of religion (based on historical material); the exploration of the essential characteristics of religion (affecting our understanding of its history); determining the universals of religion such as "belief", "community", "tradition" etc., as opposed to concepts proper to particular religions (such as "the church", etc); classification of religious Weltanschauungen, (this task is of particular importance since many concepts such as "pantheism" have blurred boundaries); clarifying concepts also in the field of classification of religions themselves (such concepts as "world religions", etc); comparative studies of religions; thematizing philosophy-in-religion (in its two forms of rational theology and religious philosophy) as one of the objects of study of philosophy of religion; metatheoretical discourse with regard to sciences of religion discerning their various (not always conscious) philosophical presumptions and clarifying their main concepts such as "religious experience", "sacred and profane", etc.; critical self-reflection due to the self-reflective character of philosophy tout court . Another way of selfknowledge for Philosophy of religion is to reflect on the history of its own field of study; indeed, many important insights not to be neglected belong to the thinkers of the past; their oblivion is detrimental also to the contemporary state of knowledge.

Having delimited the field of philosophy of religion, the Author applies his eliminative method to views on the genesis of this discipline. This leads him to the conclusion that its origin remounts to the 18th century, when other philosophies-of ... (or, as the author calls them, philosophies of the genitive case) appeared such as philosophy of history and philosophy of law, which claimed metatheoretical competence with regard to the corresponding disciplines. However, the ground for the emerging discipline was prepared in the 17th century and by that time much experience had been accumulated since antiquity. This discipline can be defined as religiology (the author uses and specifies this term introduced by German theologians in the 1920-s) as distinct both from theology (since its task is to understand religion and not to work out religious beliefs) and from empirical sciences of religion (since it seeks for the essences of religion). 
The second part of the book aims at demonstrating the historical development of eidetic characteristics of philosophy of religion and therefore is based on dialectics between the conceptual and historical moments. Shokhin shows in what way the conception of philosophy of religion presented by him was formed and actualized in history. It is impossible to present here even briefly this rich and well documented analysis, so we have necessarily to limit ourselves to some aspects of it.

First of all the author delineates the periods of formation of philosophy of religion which are as follows:

(1) Protoreligiology (VI-V BC - $1600 \mathrm{AD})$

(2) Early religiology (1601-1772)

(3) Mature religiology (1773-1800)

(4) Late religiology (1801-1830)

(5) Contemporary philosophy of religion (since 1830s).

Different tasks singled out by the author were differently realized and accentuated in particular epochs; many of these tasks and problems were formulated as early as in antiquity. Cicero, for example, offered a definition of religion which is still up-to-date ("religion permits human beings to serve and worship the supreme order of nature called divine") and neatly distinguished religion from superstition (the latter being a pragmatic approach to the divine). In the patristic period, Lactance interpreted the term religio as derived from religare and thereby emphasized the interpersonal connection between man and God; this personalistic understanding of religion permitted him to argue that authentic religion is based on free choice.

In further chapters of the second part, Shokhin has gathered and analysed extremely rich historical material. As was mentioned above, he does not limit himself to mere presentation, but critically evaluates the contribution of every philosopher and of every epoch under study to the formation and self-reflection of philosophy of religion as a philosophical discipline.

In the end of the book Vl. Shokhin resumes the advancing movement towards delimiting the concept of religion and specifying the concept of philosophy of religion; the latter finally leads to Fichte who distinguished three levels of discourse of philosophy of religion: phenomenology of the religious sense, ontology of the religious relation and general philosophy-on-religion aimed in particular at studying the religious realities and defining religion (p. 700). As for the worldviews of religiologists, three patterns prevail: naturalist exposure of religion, 
constructing "a self-made religion" (it has found its classical expression in the various forms of deism) and apology of real religion. The last pattern contradicts rationality less than the first one and runs counter to the ethos of religiosity less than the second one, but all the three of them, according to the author, recur nowadays and will recur in the future as long as philosophy of religion exists (pp. 752-753).

Shokhin's book is undoubtedly a significant event in the Russian philosophy of religion. Thanks to its carefully selected and critically analysed historical basis it is destined to become a book of reference in Russia. But it could also fit into the horizon of discussion of Philosophy of religion of the English speaking world since it constitutes a wellgrounded and well documented argument in support of a particular vision of Philosophy of religion - indeed, if the first part provides a conceptual argument in favor of this vision, the second part constitutes a historical argument to the same effect.

This development might be reproached as being based on a judgment of taste or on a preconception. This would be so if the argument in question had exactly the form the author sometimes tends to think it has; but in fact it is more complex. Indeed, Shokhin often formulates his argument in a linear way as if the view on the historical development of philosophy of religion was unidirectionally determined by its conceptual definition. However, if we look more closely at the real logical form of the argument in the book, we will see that we deal with mutual dependence between the two concepts since the conceptual definition is itself inherited from history and has been crystallized as a result of historical development. Therefore the relation between the conceptual and historical moments takes the form of hermeneutic circle in which the conceptual definition informs the understanding of historical development but at the same time results from it. It is a process in which the historical clarifies the conceptual and is in its turn clarified by the latter. Is it a vicious circle? We can decisively affirm it is not, but in order to get convinced of that one has to read Shokhin's book. 